\title{
Effects of Selected Pesticidal Plants on Termites Affecting Maize Production in Arusha, Tanzania
}

\author{
Shaban James ${ }^{1,2}$, Patrick A. Ndakidemi ${ }^{1}$, Ernest R. Mbega ${ }^{1}$ \\ ${ }^{1}$ Department of Sustainable Agriculture, Biodiversity and Ecosystems Management, Nelson Mandela African Institution of Science \\ and Technology, Arusha, Tanzania \\ ${ }^{2}$ African Development Bank Capacity Building Project, Nelson Mandela African Institution of Science and Technology, Arusha, \\ Tanzania \\ Email: jamess@nm-aist.ac.tz
}

How to cite this paper: James, S., Ndakidemi, P.A. and Mbega, E.R. (2020) Effects of Selected Pesticidal Plants on Termites Affecting Maize Production in Arusha, Tanzania. American Journal of Plant Sciences, 11, 510-527.

https://doi.org/10.4236/ajps.2020.113036

Received: August 26, 2019

Accepted: March 24, 2020

Published: March 27, 2020

Copyright (C) 2020 by author(s) and Scientific Research Publishing Inc. This work is licensed under the Creative Commons Attribution International License (CC BY 4.0).

http://creativecommons.org/licenses/by/4.0/

\begin{abstract}
Investigations under laboratory and field conditions were carried out with purpose of understanding the effects of pesticides of Cupressus lusitanica, Tephrosia vogelii, Eucalpytus dalrympleana, Lantana camara and Azadirachta indica in the control of termites which affect maize production in Arusha, Tanzania. Termites were collected before and during maize season of 2018 and identified at the Tropical Pesticides Research Institute (TPRI) laboratory. A total of 5279 out of 5307 termite species identified belong to genus Macrotermes, 23 species to genus Odontotermes and 5 species were unknown. The results entailed that the area is rich in species of genus Macrotermes. Moreover, concentrations i.e. $5 \mathrm{~g}, 10 \mathrm{~g}$ and $20 \mathrm{~g}$ of each botanical were tested for Macrotermes spp. mortality and repellency ability in the laboratory using a completely randomized design (CRD) with three replicates. The results showed that $98.33 \%$ Macrotermes spp. mortality was caused by $T$. vogelii followed by $93.33 \%$ recorded from E. dalrympleana after 24 hours. Besides, $C$. lusitanica repelled Macrotermes spp. by $97 \%$ followed by $95 \%$ recorded from $T$. vogelii and $E$. dalrympleana each. For field trials, $20 \mathrm{~g}$ of each botanical was applied using randomized complete block design (RCBD) with four replicates. The results obtained from field indicated that $T$. vogelii was more effective to protect maize with an average of 6 maize stands and $3.4 \mathrm{~kg}$ of dry total weight of maize grains next to positive control per plot. Also, average of 4 maize stands and $3 \mathrm{~kg}$ dry total weight of maize grains were recorded from treatments of $E$. dalrympleana and $C$. lusitanica each. Such results highlight the potential of developing bio-termiticides from $T$. vogelii, C. lusitanica and E. dalrympleana to control Macrotermes spp.
\end{abstract}

\section{Keywords}

Damage, Mortality, Pesticidal Plants, Repellency, Termites, Maize 


\section{Introduction}

Maize is one of the staple food crops that are rich in carbohydrates and it is consumed by the majority of people in Africa [1] [2]. It is also used as the source of income by the most African communities [1]. The crop is of importance for livelihood of people, yet its production is constrained by various insect pests such as termites [3]. The most known destructive termite species to maize include Microtermes spp., Macrotermes spp. and Pseudacanthotermes spp. [4]. These species have been reported to cause high losses in pre- and post-harvest of maize in developing countries. For example, in some African countries, such as Mozambique, Zambia, Uganda and Malawi, damage on different crops including maize has been reported [2] [5]. In other African countries, such as Ethiopia, $45 \%$ - 50\% maize damage has been documented [6] [7]. In addition, effects of termites to other crops, for example, groundnuts and coconuts, have been documented; Nigeria, Burkina-Faso, Niger and Mali encounter a loss of $30 \%$ in groundnuts annually [8] and up to 50\% groundnuts loss occurs in India yearly [9]. In Tanzania, damage by termites on coconuts $(20 \%-100 \%)$ has been reported especially during the dry seasons [10].

Furthermore, in Arusha region of Tanzania, termites have been reported to attack agricultural crops, some trees in gardens and public parks [11] [12]. Managing termites is possible with use of synthetic pesticides, however, the chemicals are hazardous to the environment and people [13] [14] [15]. So, search for alternative, affordable, eco-friendly and appropriate management strategies for insect pests such as use of bio-pesticidal plants is urgently needed [16] [17]. Previous studies have shown that T. vogelii, Eucalyptus spp., A. indica, C. Iusitanica and L. camara are commonly used by small scale farmers of Tanzania and Uganda to control moths, weevils, aphids, stem borers, rodents, pod borers, bean flies and termites in field crops [18] [19]. In addition, leaves of $C$. lusitanica have been used to treat cold and cough symptoms, treat dermatophytes on human skin and repelling insect pests from stored seeds or grains [20]. In other studies, a repellency of $73 \%$ to $90 \%$ on treated Prostephanus truncatus has been obtained from research conducted by [21] using leaf powders of $A$. indica, L. camara and T. vogelii. In Africa, crushed fresh leaves of $T$. vogelii are used as poisons for illegal fishing especially in rural areas [22].

Besides, report by Ogendo et al. (2003) concluded that leaf powders of T. vogelii can cause up to $94 \%$ mortality in Sitophilus zeamais (Motsculsky), Rhyzopertha dominica (F.), Sitophilus oryzae (L.), Callosobruchus chinensis (L.), Oryzaephilus surinamensis (L.) and Tribolium castaneum (Herbst) candidates under laboratory conditions [23]. Also, Eucalyptus powders have been found to be strong to control $S$. zeamais in stored maize grains within 56 days [24]. The diverse use of these pesticidal plants is due to presence of bioactive compounds. For instance, T. vogelii possesses high amounts of rotenone and deguelin [25]. Rotenone and deguelin are toxic compounds and can kill many aquatic organisms including fishes since they are poisons when introduced into water [26]. 
They have ability to inhibit the function of respiratory enzymes in fishes [27]. Lantana camara contains ursolic acid stearoylglucoside as active compound which causes dehydration, lung and heart problems, nephrosis, constipation, less mobility and lowering reproduction in animals such as mice [28] [29]. Besides, Azadirachta indica contains Azadirachtin compounds which when it comes into contact with beneficial insects affect by repelling them from their homes and causes feeding deterrence, blocking sugar and receptor cells, disrupting growth and moulting, inhibits oogenesis and oviposition in female and interrupts sperm production in male insects [30]. The C. lusitanica and E. dalrympleana leaves have aromatic compounds and compounds of essential oils including $\alpha$-cedrene, $\beta$-cedrene, bornyl acetate, cedrol, epimanool, agathadiol and 1,8-cineole [31] [32]. When these compounds are not handled well during field application, can suppress other non-targeted organisms like beneficial insects. For example, it has been reported that these compounds can repel and affect important agricultural crop pollinators such as butterflies [33].

Regarding the above potential highlights of botanical powders as control agents for crop plant insect pests, the current study was designed to identify termites affecting maize production and evaluate the efficacy of leaf powders of T. vogelii, E. dalrympleana, A. indica, C. lusitanica and L. camara against termite species from laboratory to field applications.

\section{Materials and Methods}

\subsection{Study Area Description}

The study was conducted at Kikwe Ward in Arumeru District of Arusha region. The district has area of $2966 \mathrm{~km}^{2}$ equivalent to $3.5 \%$ of Arusha region, located between $35^{\circ} \mathrm{E}$ and $37^{\circ} \mathrm{E}$ longitudes as well as $3^{\circ} \mathrm{S}$ latitudes [34]. Arumeru district receives bimodal rainfall, March to May and November to December. The average monthly rainfall is about $83.3 \mathrm{~mm}$ to $375 \mathrm{~mm}$ and temperatures of about $20^{\circ} \mathrm{C}$ to $35^{\circ} \mathrm{C}$ [35]. The main crops grown in Arumeru district are coffee, beans, banana, vegetables and maize [36] [37].

The area harbors a high population of termites that affect maize crops, however, no quantified figures are available on maize loss. Therefore, three sites namely A, B and C located at $03^{\circ} 25^{\prime} 23.2^{\prime \prime} \mathrm{S}$ and $036^{\circ} 48^{\prime} 03.0^{\prime \prime} \mathrm{E}, 03^{\circ} 25^{\prime} 28.3^{\prime \prime S}$ and $036^{\circ} 48^{\prime} 00.7^{\prime \prime} \mathrm{E}$ and $03^{\circ} 25^{\prime} 30.5^{\prime \prime S}$ and $036^{\circ} 47^{\prime} 43.1^{\prime \prime} \mathrm{E}$ respectively, were established in this Ward at Gomba farms for the study (Figure 1). Also laboratory experiments were carried out at the Nelson Mandela African Institution of Science and Technology (NM-AIST) and the Tropical Pesticides Research Institute (TPRI) laboratories.

\subsection{Source of Pesticidal Plants Used in this Study}

Leaves of C. lusitanica, T. vogelii, E. dalrympleana, L. camara and A. indica were collected in January 2018 from their natural environments at Nambala village in Kikwe Ward. The leaves collected were air dried at room temperature of $25^{\circ} \mathrm{C}$ in 


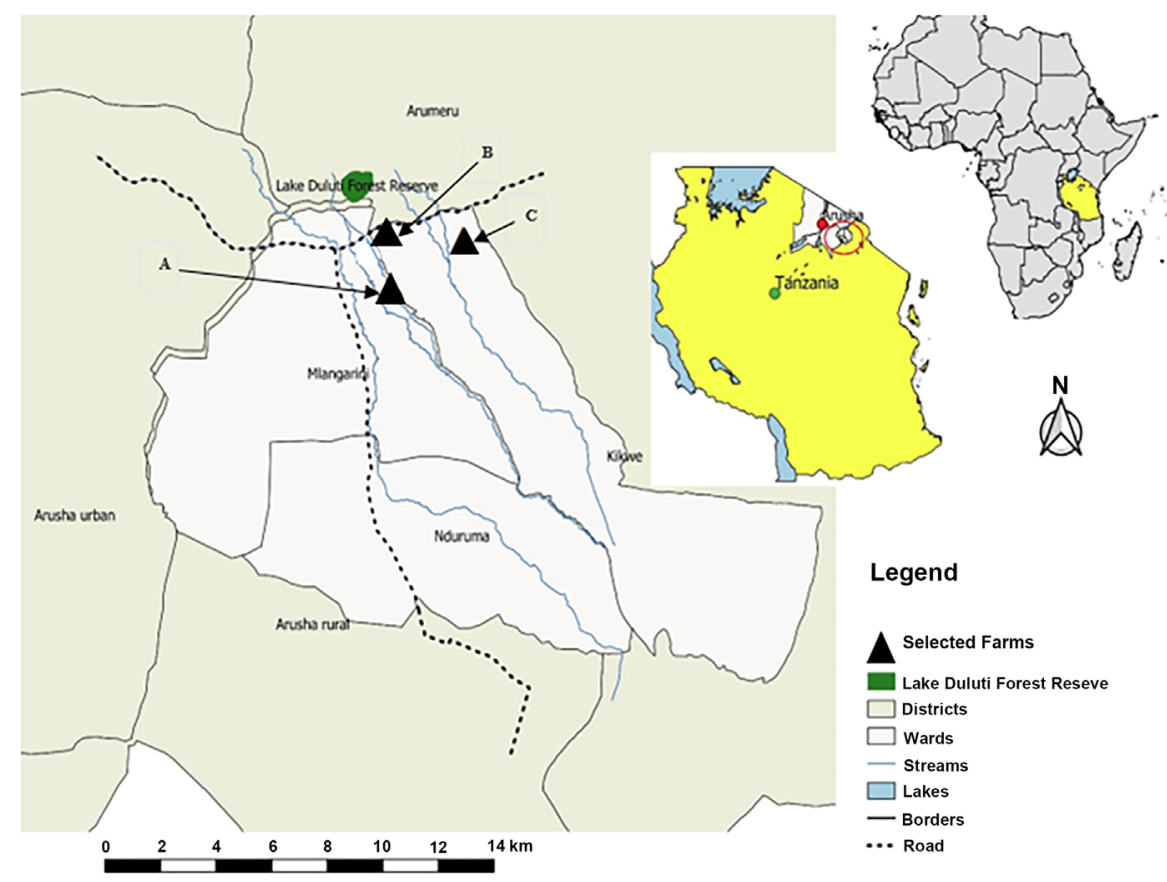

Figure 1. Study site.

the NM-AIST laboratory for 21 days [38]. All dried leaves were crushed separately into 35 grams of powders, packed, labeled and stored in dark room (NM-AIST laboratory) prior to use. The powder size used in this study was 5, 10 and 20 grams adopted with modification [24].

\subsection{Termite Sampling before Maize Season}

Before maize season (January to February 2018) three sites from three farms were purposively selected at Kikwe ward based on history of presence of termites. In each farm two transects of $100 \mathrm{~m}$ long were established and quadrats of $5 \mathrm{~m} \times 2 \mathrm{~m}$ were conducted twenty times along each transect at interval of $5 \mathrm{~m}$ based on Coulibaly et al. (2013) protocol with modifications [39]. From each quadrat five holes were randomly dug up to $20-30 \mathrm{~cm}$ depth to collect termites (soldier castes and worker castes). In each hole 4 termites were collected making a subtotal of 20 termites per quadrat and a total of 400 termites per transect and a total of 800 termites/farm. As per methodology a total of 2400 termites were collected from three farms and put into different labeled (with respect to location) small bottles (diameter $3 \mathrm{~cm}$, height $5 \mathrm{~cm}$ ) containing $70 \%$ alcohol prior to identification.

\subsection{Termite Sampling during Maize Season}

From March to July 2018, termites (both soldier and worker castes) were collected randomly from three experimental sites (experimental plots). Holes were dug up to $20-30 \mathrm{~cm}$ depth to search and collect termites following systematic random sampling technique. A total of 2907 termites were collected from all experimental plots. This sampling process was done once per month until harvest. 


\subsection{Termite Identification}

A total of 2400 termites (before field experiments) and 2907 termites (from experimental plots during maize season of 2018) were transported to Tropical Pesticides Research Institute laboratory for identification. Soldier castes were sorted and their morphological features were observed using Stereo-microscope based on Bouilon and Mathot (1965) and Pearce et al. (1992) methodology [40] [41].

\subsection{Collection of Termites for Laboratory Experiments}

Termite species of genus Macrotermes were collected from three experimental sites/plots. At these sites holes were dug up to $20-30 \mathrm{~cm}$ following systematic random sampling. Soil containing Macrotermes spp. was placed on the polyethene plastic sheet, then termites were swept into ventilated polyethene plastic boxes $(22 \times 7 \times 7)$ using camel hair brushes [42]. The Macrotermes spp. preferred feeding plant materials (sun dried maize leaves and stems) were added followed by moistened cotton wool to maintain moisture condition (65\%) for the survival of the termites [43]. The selection to species of genus Macrotermes in this study has basically considered the effects of these species in maize production before harvesting in Arumeru district.

\subsection{Testing the Efficacy of Pesticidal Plants on Termite Mortality and Repellency}

A completely randomized design (CRD) was used using seven treatments on pot experiments in triplicates for the mortality test. The pots $(28.8 \mathrm{~cm}$ in height and $25 \mathrm{~cm}$ diameter) were filled with termite mound soil of $5 \mathrm{~kg}$ and in each bucket, 2 liters of tap water was added and left to drain for one hour. Then on each bucket, about 20 termites of genus Macrotermes from the same colony were added followed by addition of powder of the treatment. One gram of Bakiller dust (Carbaryl $5 \% \mathrm{w} / \mathrm{w}+$ Lambdacyhalothrin $0.1 \% \mathrm{w} / \mathrm{w}$ ) was used as positive control based on manufacture's recommendation whereas $5 \mathrm{~g}$ powder prepared from mixture of sun dried leaves and stems of maize (Macrotermes spp. preferred feeding plant materials) was used as negative control. Thereafter, all buckets were covered with ventilated wire mesh covers to prevent termites from escaping. Three different rates $(5 \mathrm{~g}, 10 \mathrm{~g}$ and $20 \mathrm{~g}$ powder per $5 \mathrm{~kg}$ soil) of $C$. $1 \mathrm{lu}$ sitanica, $T$. vogelii, E. dalrympleana, L. camara and $A$. indica were used. The mortality rates were recorded at 6,12,18 and 24 hours after application.

To test the ability of the plants to repel the termites, the experiments were set as per the previously described mortality experiments with an exception that, the powder of the test plants (C. lusitanica, T. vogelii, E. dalrympleana, L. camara and $A$. indica) at similar rates was poured on top of soil in the bucket to half the diameter (Figure 2) and twenty termites of the same colony were placed on the center of the bucket and were visually observed whether or not they would move away or towards the plant powders. As of the previous description, this 


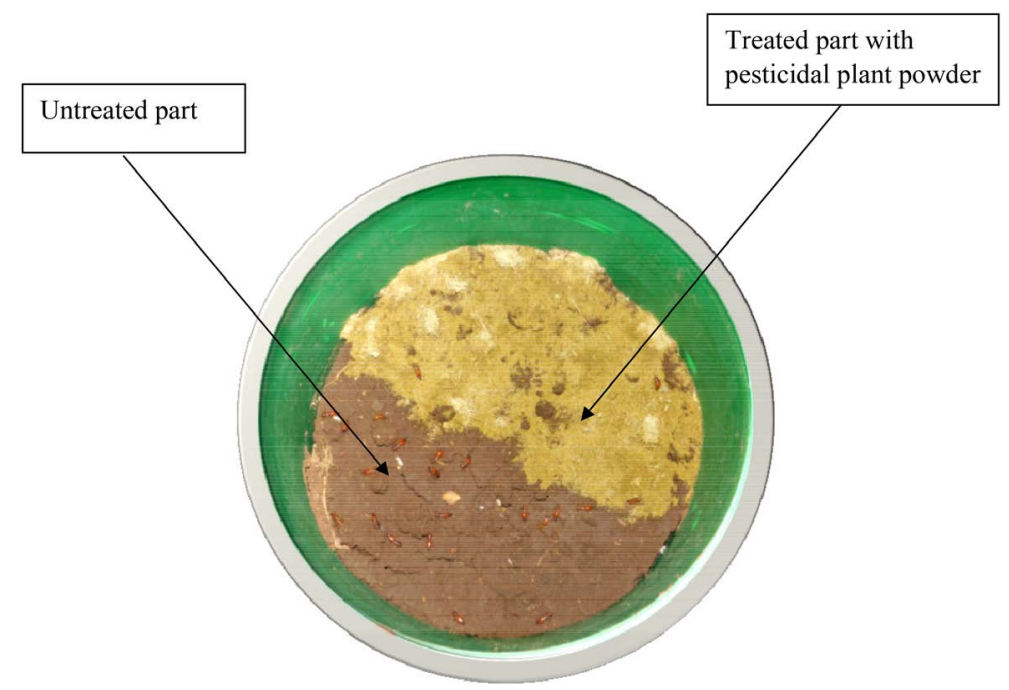

Figure 2. Repelled termites by C. Iusitanica (among plant powder treatments).

experiment was arranged in a completely randomized design (CRD) with three replicates. The repellency ability of the treatment was recorded after one hour.

\subsection{Testing the Efficacy of the Pesticidal Plants in the Fields}

For field experiments, three sites were established for trials in Gomba maize farms where there is high abundance of Macrotermes spp. which affect maize production before harvesting. The experiments were conducted during maize growing season from March to July in 2018 and the distance from one site to another was 500 meters. In each site, every plot had $150 \mathrm{~cm}$ long and $90 \mathrm{~cm}$ wide and the distance separation from plot to plot was $50 \mathrm{~cm}$. Eight maize plants (PAN 691) were germinated in each plot (two rows each with 4 maize plants planted each at spacing of $30 \mathrm{~cm}$ by $75 \mathrm{~cm}$ ). After two weeks of germination, Basal fertilizers containing nitrogen, phosphorus potassium (NPK) and urea were applied to enhance maize growth. Thereafter, five treatments of leaf powders prepared from C. lusitanica, T. vogelii, E. dalrympleana, L. camara and A. indica at the rate of $20 \mathrm{~g}, 2 \mathrm{~g}$ of positive control [Bakiller dust (Carbaryl 5\% w/w + Lambdacyhalothrin $0.1 \% \mathrm{w} / \mathrm{w})]$ and without treatments as negative control were applied in the third week following randomized complete block design (RCBD) in four replications. Botanical leaf powders and Bakiller dust were applied around the maize stems. The application of botanical leaf powders and the controls were re-applied and monitored on treated plants every after 14 days until harvest.

\subsection{Data Collection}

Termites were collected from the field for identification, a number of dead termites were recorded while repelled termites were counted and recorded from both treated and untreated samples. The termite mortality (\%) and repellency rate (\%) were calculated using Equation (a) and (b) as described by [32] and 
[43], respectively. Since each plot had 8 maize plants before damage by termites, careful counting and recording of maize stands was done to each plot in respect to treatments. Also average total dry weight of maize grains were obtained from only maize stands in respect to treatments. On the other hand, maize which found fallen down due to termite damage was not considered for harvest.

$$
P M=\frac{(M T T-M T C)}{(100-M T C)} \times 100
$$

$P M=$ Percent Mortality

$M T T=$ Mortality of Termites in Treatment

$M T C=$ Natural Mortality of Termites in Control

$$
P R=\frac{(T-C)}{(T)} \times 100
$$

$P R=$ Percent repellency

$T=$ All termites counted from the part without treatment

$C=$ All termites counted from the part with treatment

\subsection{Data Analysis}

Collected termites from field were identified to genus level. Also before Analysis of Variance (ANOVA), Bartlett's test was run using R- Studio on collected data of termite mortality, repellency, average maize stands and average total dry weight of maize grains produced. The output showed that the p-values for mortality, repellency, average maize stands and average total dry weight of maize grains were $0.4009,0.9966,0.9290$ and 0.0820 , respectively. This means that we cannot reject the null hypothesis because the $p$-values are not less than 0.05 . Or there is no evidence to suggest that the variances in mortality, repellency, average maize stands and average total dry weight of maize grains are different from treatments. Therefore, an option to transfer data to Analysis of Variance (ANOVA) was done to determine the significant differences. Differences among treatment means were determined using Duncan's multiple range test at $p=0.05$ using GenStat 15 edition statistical package.

\section{Results}

\subsection{Identified Termites}

The results in Table 1 showed that 5279 (99.47\%) out of 5307 were identified as Macrotermes spp., $23(0.43 \%)$ as Odontotermes spp. and $5(0.09 \%)$ as unknown species. Based on this study, five (5) termites were not identified to genus level due to available limited technology at the Tropical Pesticides Research Institute.

\subsection{Mortality of Macrotermes spp.}

The results in Table 2 showed that there was a significant difference $(p \leq 0.001)$ between effect of different insecticidal plants ( $C$. Iusitanica, $T$. vogelii, E. daIrympleana, $L$. camara and $A$. indica) against Macrotermes spp. compared with 
Table 1. Some termites identified to genus level.

\begin{tabular}{cc}
\hline Termite Genera & Number of termites \\
\hline Macrotermes & 5279 \\
Odontotermes & 23 \\
Unknown X & 2 \\
Unknown Y & 3 \\
Total & 5307 \\
\hline
\end{tabular}

Table 2. Effect of different insecticidal plants on Macrotermes spp. (mortality).

\begin{tabular}{|c|c|c|c|c|c|}
\hline \multirow[t]{2}{*}{ Treatments } & \multirow{2}{*}{$\begin{array}{l}\text { Rate in g/ } \\
5 \mathrm{~kg} \text { soil }\end{array}$} & \multicolumn{4}{|c|}{ Mortality mean in percent (\%) per time (hours) } \\
\hline & & 6 & 12 & 18 & 24 \\
\hline T. vogelii & 5 & $35.0 \pm 2.89 \mathrm{~d}$ & $73.3 \pm \pm 3.33 \mathrm{hi}$ & $90.0 \pm 2.89 \mathrm{f}$ & $93.3 \pm 1.67 \mathrm{i}$ \\
\hline T. vogelii & 10 & $50.0 \pm 5.77 \mathrm{e}$ & $83.3 \pm 4.41 \mathrm{j}$ & $93.3 \pm 1.67 \mathrm{fg}$ & $96.7 \pm 1.67 \mathrm{i}$ \\
\hline T. vogelii & 20 & $78.3 \pm 4.41 \mathrm{~g}$ & $88.3 \pm 3.33 j$ & $95.0 \pm 2.89 \mathrm{fg}$ & $98.3 \pm 1.67 \mathrm{i}$ \\
\hline L. camara & 5 & $5.0 \pm 2.89 \mathrm{ab}$ & $10.0 \pm 2.89 \mathrm{abcde}$ & $11.7 \pm 1.67 \mathrm{bc}$ & $23.3 \pm 1.67 \mathrm{cdef}$ \\
\hline L. camara & 10 & $5.0 \pm 2.89 \mathrm{ab}$ & $11.7 \pm 1.67 \mathrm{bcdef}$ & $13.3 \pm 1.67 \mathrm{bc}$ & $16.7 \pm 1.67 \mathrm{bc}$ \\
\hline L. camara & 20 & $10.0 \pm 2.89 \mathrm{ab}$ & $18.3 \pm 3.33 \mathrm{cdef}$ & $20.0 \pm 2.89 \mathrm{~cd}$ & $33.3 \pm 1.67 \mathrm{~g}$ \\
\hline C. lusitanica & 5 & $1.7 \pm 1.67 \mathrm{a}$ & $10.0 \pm 2.89 \mathrm{abcd}$ & $11.7 \pm 1.67 \mathrm{bc}$ & $20.0 \pm 2.89 \mathrm{bcde}$ \\
\hline C. lusitanica & 10 & $5.0 \pm 5.00 \mathrm{ab}$ & $10.0 \pm 5.77 \mathrm{bcd}$ & $11.7 \pm 4.41 \mathrm{bc}$ & $20.0 \pm 2.89 \mathrm{bcd}$ \\
\hline C. lusitanica & 20 & $3.3 \pm 1.67 \mathrm{a}$ & $10.0 \pm 2.89 \mathrm{abcd}$ & $20.0 \pm 2.89 \mathrm{~cd}$ & $23.3 \pm 6.01 \mathrm{cdef}$ \\
\hline A. indica & 5 & $8.3 \pm 4.41 \mathrm{ab}$ & $8.3 \pm 4.41 \mathrm{abc}$ & $11.7 \pm 6.01 \mathrm{bc}$ & $16.7 \pm 4.41 \mathrm{bc}$ \\
\hline A. indica & 10 & $0.0 \pm 0.00 \mathrm{a}$ & $5.0 \pm 0.00 \mathrm{ab}$ & $6.7 \pm 1.67 \mathrm{ab}$ & $11.7 \pm 6.67 \mathrm{~b}$ \\
\hline A. indica & 20 & $15.0 \pm 5.77 b c$ & $20.0 \pm 2.89 \mathrm{df}$ & $23.3 \pm 1.67 \mathrm{~d}$ & $30.0 \pm 0.00 \mathrm{dfg}$ \\
\hline E. dalrympleana & 5 & $21.7 \pm 4.41 \mathrm{c}$ & $55.0 \pm 2.89 \mathrm{~g}$ & $71.7 \pm 3.33 \mathrm{e}$ & $80.0 \pm 2.89 \mathrm{~h}$ \\
\hline E. dalrympleana & 10 & $45.0 \pm 2.89 \mathrm{de}$ & $70.0 \pm 2.89 \mathrm{~h}$ & $76.7 \pm 4.41 \mathrm{e}$ & $83.3 \pm 4.41 \mathrm{~h}$ \\
\hline E. dalrympleana & 20 & $65.0 \pm 2.89 \mathrm{f}$ & $80.0 \pm 2.89 \mathrm{ij}$ & $93.3 \pm 1.67 \mathrm{fg}$ & $93.3 \pm 1.67 \mathrm{i}$ \\
\hline Positive control & 1 & $100.0 \pm 0.00 \mathrm{~h}$ & $100.0 \pm 0.00 \mathrm{k}$ & $100.0 \pm 0.00 \mathrm{~g}$ & $100.0 \pm 0.00 \mathrm{i}$ \\
\hline Negative control & 5 & $0.0 \pm 0.00 \mathrm{a}$ & $0.0 \pm 0.00 \mathrm{a}$ & $0.0 \pm 0.00 \mathrm{a}$ & $0.0 \pm 0.00 \mathrm{a}$ \\
\hline LSD & & 10.147 & 9.057 & 8.057 & 9.127 \\
\hline $\mathrm{p}$ value & & 0.001 & 0.001 & 0.001 & 0.001 \\
\hline
\end{tabular}

Means followed by the same letter (s) at the same column are not significant different at $p=0.05$ using Duncan's Multiple Range Test.

negative control. T. vogelii and E. dalrympleana were the most effective plants which caused the highest mortality of Macrotermes spp. at 6, 12, 18 and 24 hours. All rates of $T$. vogelii $(5 \mathrm{~g}, 10 \mathrm{~g}$ and $20 \mathrm{~g}$ ) and that of E. dalrympleana (20 g) had no significant difference from positive control after 24 hours. Moderate mortalities with $23.33 \%, 30 \%$ and $33.33 \%$ were recorded from C. lusitanica, $A$. indica and $L$. camara, respectively at rate of $20 \mathrm{~g}$ each one. 


\subsection{Repellency of Macrotermes spp.}

The results showed significant difference $(p \leq 0.001)$ between treatments in repellency of Macrotermes spp. (Table 3). The percent repellency values recorded in treatments of $C$. lusitanica at $5 \mathrm{~g}, 10 \mathrm{~g}$ and $20 \mathrm{~g}$ have non- significant difference with that of $T$. vogelii ( $10 \mathrm{~g}$ and $20 \mathrm{~g}$ ) and E. dalrympleana (10 $\mathrm{g}$ and $20 \mathrm{~g}$ ). But, the percent repellency values recorded from $A$. indica and $L$. camara treatments were lower than that obtained from C. lusitanica, T. vogelii and E. daIrympleana.

\subsection{Effects of Pesticidal Plants Powder on Field Maize in Three Sites (at Gomba Maize Farms)}

The results in Figure 3 show that there was a significant reduction $(p \leq 0.001)$ of maize crops damaged by termites (Macrotermes spp.) in treated plots compared with untreated plots. Average of maize stands per plot was 6.01, 4.16 and 3.96 with treatment of $T$. vogelii, $E$. dalrympleana and $C$. lusitanica, respectively. High average of maize grain yields were obtained from plots with treatment of $T$. vogelii $(3.4 \mathrm{~kg})$ followed by E. dalrympleana $(2.93 \mathrm{~kg})$ and C. lusitanica $(2.58 \mathrm{~kg})$ as depicted in Figure 4.

Table 3. Repellency bioassay in treated Macrotermes spp.

\begin{tabular}{ccc}
\hline Treatments & Rate in $\mathbf{g}$ kg soil & Average percent repellency \\
\hline T. vogelii & 5 & $88.3 \pm 7.27 \mathrm{bc}$ \\
T. vogelii & 10 & $95.0 \pm 4.41 \mathrm{c}$ \\
T. vogelii & 20 & $95.0 \pm 3.33 \mathrm{c}$ \\
L. camara & 5 & $76.7 \pm \pm 4.41 \mathrm{~b}$ \\
L. camara & 10 & $76.7 \pm 6.01 \mathrm{~b}$ \\
L. camara & 20 & $77.7 \pm 10.14 \mathrm{~b}$ \\
C. Iusitanica & 5 & $95.0 \pm 1.67 \mathrm{c}$ \\
C. Iusitanica & 10 & $95.0 \pm 1.67 \mathrm{c}$ \\
C. Iusitanica & 20 & $96.7 \pm 2.89 \mathrm{c}$ \\
A. indica & 5 & $76.7 \pm 7.64 \mathrm{~b}$ \\
A. indica & 10 & $83.3 \pm 4.41 \mathrm{bc}$ \\
A. indica & 20 & $83.3 \pm 4.41 \mathrm{bc}$ \\
E. dalrympleana & 5 & $86.7 \pm 8.82 \mathrm{bc}$ \\
E. dalrympleana & 10 & $93.3 \pm 3.33 \mathrm{c}$ \\
E. dalrympleana & 20 & $95.0 \pm 2.89 \mathrm{c}$ \\
Negative control & 5 & $0.0 \pm 0.00 \mathrm{a}$ \\
LSD & & 13.320 \\
p value & & 0.001 \\
\hline . & 5 & \\
\hline
\end{tabular}

Means with the same letter (s) have no significant difference at $p=0.05$ using Duncan's Multiple Range Test. 


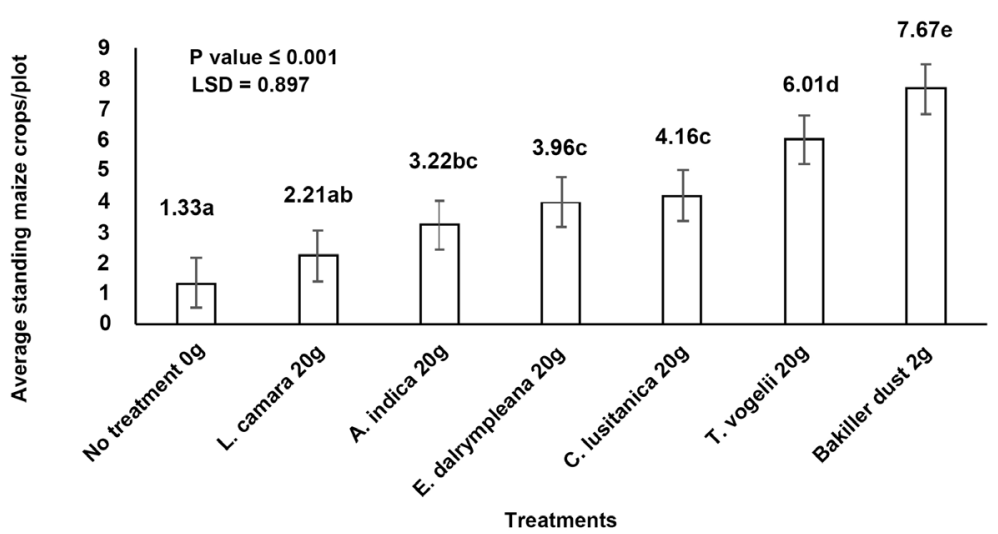

Figure 3. Average of standing maize plants treated with different pesticidal plants and control (A, B and C).

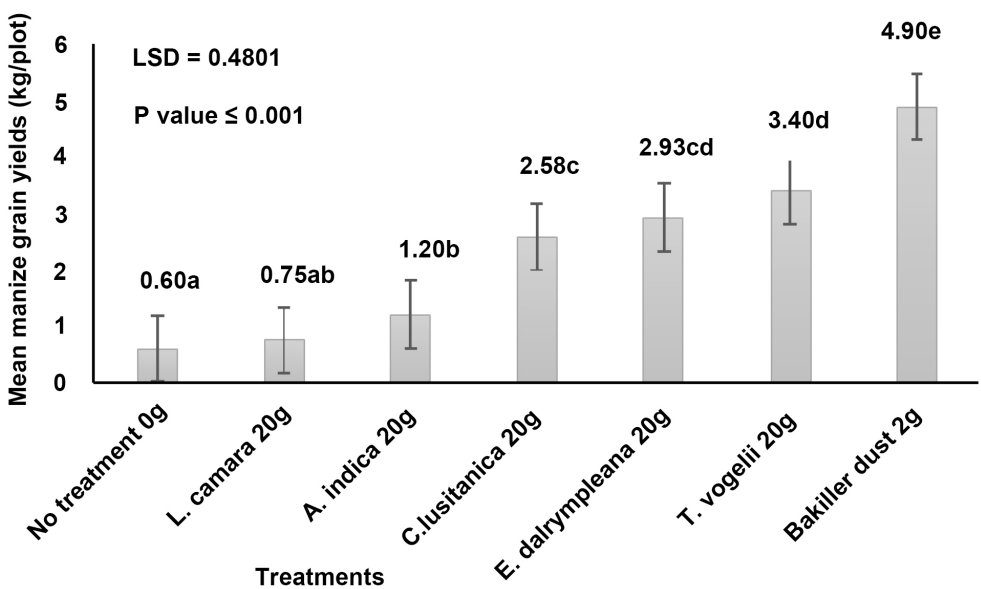

Figure 4. Average total dry weight of maize grains per plot from all sites (A, B and $\mathrm{C})$.

\section{Discussion}

This study identified only termite species of genera Macrotermes and Odontotermes whereas species of unknown genera ( $\mathrm{X}$ and $\mathrm{Y}$ ) were not identified due to available limited technology at the Tropical Pesticides Research Institute laboratory. The number of termite species identified for genus Macrotermes was high compared with genus Odontotermes and unknown genus $\mathrm{X}$ and $\mathrm{Y}$. In addition, the observation made the area is richly covered with termite mounds of genus Macrotermes. The presence of termite mounds contributes to high abundance of species of genus Macrotermes which forage on maize plants intensively. Their foraging behavior affect maize production and this is why the current study concentrated only in trials of botanical powders against species of genus Macrotermes. These findings present one of very few accounts on maize in Tanzania and they are in line with several studies. In India, species of genus Macrotermes have been reported to cause a loss up to $25 \%$ in maize yields per year before harvesting [44]. Furthermore, in Uganda, the same has been reported to cause 10 to $30 \%$ of maize loss before and after harvest [2] [45]. The Macrotermes can also 
cause up to $100 \%$ damage on maize [46]. Urgent management strategies which are eco-friendly and affordable are needed to control Macrotermes spp. such as use of botanical pesticides. Less or no studies have been conducted in control of Macrotermes spp. using leaf powders from C. lusitanica, T. vogelii, E. dalrympleana, L. camara and $A$. indica on maize fields. The discussion has been related with different studies conducted in different insect pests other than termites, Macrotermes spp. due to available limited information.

Interestingly, $T$. vogelii leaf powders were the most effective pesticide against Macrotermes spp. causing a mortality of $98.33 \%(20 \mathrm{~g})$ for 24 hours. These results relate to study of Ogendo et al. (2003) which showed that leaf powder from T. vogelii caused a mortality of 85 to $94 \% S$. zeamais in stored food products [23]. Moreover, T. vogelii powder reduced the number of eggs laid for first progeny (insect bruchids) resulting into $7.1 \%$ stored leguminous seeds damage compared with $99.8 \%$ damage in control without treatments [47]. Besides, the leaf powders of $T$. vogelii caused $93.3 \%$ C maculatus mortality at concentration of $3 \mathrm{~g}$ per $10 \mathrm{~g}$ of stored cowpea seeds on the 96 hours [48].

Other results of the current study were recorded from leaf powders of $E$. daIrympleana, C. Iusitanica, A. indica and L. camara. Among these, E. dalrympleana was more effective than $C$. lusitanica, $A$. indica and $L$. camara in causing mortality. However, application information availability for E. dalrympleana is limited, but the genus Eucalyptus is highly documented for its significance in the management of diverse insect pests. For instance, research data reported by [24] proved that $10 \mathrm{~g}$ of $E$. tereticornis leaf powder can cause $91.10 \%$ mortality for 8 weeks against stored maize weevil, $S$. zeamais. These results are in agreement with the investigation which tested crude powder, $2.0 \%$ to $4.4 \% \mathrm{w} / \mathrm{w}$ of $O$. gratissimum and found that $87 \%-90 \%$ and $27 \%-50 \%$ mortality to C. maculatus and $S$. zeamais, respectively [49].

Moderate mortalities recorded from $C$. lusitanica, $A$. indica and $L$. camara could perhaps be linked to the bioactive compounds not being exposed enough to cause lethal effect on experimental termites used in the current study. However, these results cannot be ignored in comparison to negative control. These significant effects showed by these botanicals demand different technologies especially from how botanicals are prepared and extracted in order to reduce loss of bioactive ingredients/compounds. Previous studies have demonstrated efficacious results on different tested crop insect pests. For instance, $A$. indica leaf extracts minimized significantly the number of Tuta absoluta in vegetable tomatoes compared with fields without treatments [50]. The screening for mortality against Lepidopteran and Coleopteran insect pests with two botanicals showed that the extracts from C. Iusitanica and E. saligna at dose of $2.0 \% \mathrm{v} / \mathrm{w}$ caused high mortality against the pests $(84 \%-86 \%)$ [32]. This concurs with assertions by the report of [21] where L. camara leaf powder minimized significantly (70\% - 86\%) the number of Coleopteran pests from stored food cereals such as maize grains.

The repellency test presents very useful information which can be used by ecologists and conservationists who discourage killing of insects for the purpose 
of biodiversity conservation and their important roles they play in the ecosystems. For instance, termites decompose wooden components and recycle them and later on improve soil structure and texture [51]. In addition, the activities of termites in soil lead to excellent aeration and improvement of soil nutrients by adding Nitrogen $(\mathrm{N})$ and Carbon $(\mathrm{C})$ through Nitrogen $(\mathrm{N})$ fixation and Carbon (C) mineralization respectively [52].

The results of repellence bio-assay of leaf powders of $T$. vogelii, E. dalrympleana, C. lusitanica, A. indica and $L$. camara showed variations in terms of responses to tested Macrotermes spp. C. lusitanica leaf powder exhibited strong repellency followed by $T$. vogelii and $E$. dalrympleana. Their percent repellency values ranged from $95 \%$ to $97 \%$ at $20 \mathrm{~g}$ in this study. Our results are in line with a report by [32] who reported that the extracts of C. lusitanica repelled coleopteran insect pests by $65 \%$ to $93 \%$ from stored food products. These results corroborate with the report findings of study by [21] who identified that $90 \%$ repellency in stored maize weevils, $P$. truncatus was caused by $T$. vogelii powders. Though, there is limited information of E. dalrympleana, yet the species of the same genus are well studied and documented. For example, $30 \mathrm{~g}$ powder of $E u-$ calyptus globulus caused a significant repellency of $80 \%$ to termites [19] [53]. The observed repellent activities in $A$. indica and $L$. camara were moderate against Macrotermes spp. These results are closely related to the previous findings. Chebet et al. (2013) found that powders of $L$. camara and A. indica can cause a repellency of $73 \%$ and $88 \%$ on $P$. truncatus respectively [21]. Interestingly, a single topical application of $L$. camara extracts to volunteers ensured protection of $100 \%$ in 120 minutes and $75.8 \%$ for 420 minutes from bites of mosquito species (Aedes spp.) [54].

Of the five pesticidal plants evaluated, $T$ vogelii was the most effective in terms of efficacy on field Macrotermes spp. control. The results of our study relate to study conducted by Mkindi et al. (2017) in Tanzania and Malawi, which found that $T$ vogelii reduced the number of field insect pests and damage and promoting high bean yields during harvest [55]. Furthermore, field research which used crushed $T$. vogelii leaves in ponds caused a significant mortality on fishes, rotifers and larvae of mosquitoes [56]. In addition, T. vogelii is effective in controlling both stored product and field insect pests [57]. The effectiveness of $T$ vogelii is due to presence of already known active ingredients such tephrosin and deguelin [58] [59]. As rotenone has known history in the insect pest control for so long before an invention of synthetic pesticides, so registration and commercialization of $T$ vogelii products are highly needed [60]. Other promising results were obtained from treatments of $E$. dalrympleana and $C$. lusitanica. Though there is less or no quantified information about the applicability of $E$. dalrympleana, various species of genus Eucalpytus are highly recognized and reported to have considerable effects against variety of agricultural crop insect pests. For instance, field trials conducted in India during the kharif growing season in 1988 identified that the Eucalyptus globulus extracts reduced the larvae of Henosepilachna vigintioctopunctata significantly [61]. These results corroborate with the 
research findings of Paul et al. (2009) which showed a significant reduction in numbers of bean insect pests on farm trials in Northern Tanzania [62].

\section{Conclusion and Recommendations}

This study has demonstrated that there is termite species of genera Macrotermes, Odontotermes and species of unknown genera (X and Y). The species of genera Macrotermes are more abundant and destructive to maize than any other. Moreover, the current study confirms that $T$. vogelii is more effective among pesticidal plants which exhibited positive mortality of termite species of genus Macrotermes next to positive control (bakiller dust) followed by $E$. dalrympleana. The C. lusitanica, T. vogelii and E. dalrympleana showed the highest performance in repelling termites of genus Macrotermes under laboratory conditions. Also, the field trials showed that $T$. vogelii was more effective among pesticidal plants in protection of maize plants against destructive termites of genus $\mathrm{Ma}$ crotermes followed by $C$. lusitanica and $E$. dalrympleana. The average dry weight of maize grains yields in kilograms harvested from all plots with treatment of $T$. vogelii was high followed by those obtained from treatment of $E$. dalrympleana as well as C. lusitanica. This entails that $T$. vogelii, E. dalrympleana and C. lusitanica possess strong insecticidal compounds which can suppress termite species of genus Macrotermes around the treated maize crops. The study recommends more researches including molecular studies on termite diversity and identification from a wide geographical area and their role in agricultural crop damage. Also, verification of negative effects to non-targeted organisms is needed for the leaf powders prepared from $T$. vogelii, E. dalrympleana and C. Iusitanica.

\section{Authors' Contribution}

SJ and ERM proposed the research idea. Then SJ, ERM and PAN designed the research methodology and conducted the experiments. SJ did analysis of data obtained from laboratory and field experiments. The manuscript was prepared and approved by SJ, ERM and PAN.

\section{Acknowledgements}

We would like to thank the Nelson Mandela African Institution of Science and Technology (NM-AIST) for providing financial support through African Development Bank (AfDB) Grant no. 2100155032816. We extend our gratitude to Tropical Pesticides Research Institute (TPRI) of Arusha for use of the laboratory for termite identification.

\section{Human and Animal Subject}

The study does not have any data from human and animal subjects.

\section{Conflicts of Interest}

The authors declare that they have no conflict of interest. 


\section{References}

[1] Maniania, N., Ekesi, S. and Songa, J. (2002) Managing Termites in Maize with the Entomopathogenic Fungus Metarhizium anisopliae. International Journal of Tropical Insect Science, 22, 41-46. https://doi.org/10.1017/S1742758400015046

[2] Sekamatte, B., Ogenga-Latigo, M. and Russell-Smith, A. (2003) Effects of Maize Legume Intercrops on Termite Damage to Maize, Activity of Predatory Ants and Maize Yields in Uganda. Crop Protection, 22, 87-93. https://doi.org/10.1016/S0261-2194(02)00115-1

[3] Riekert, H. and Van den Berg, J. (2003) Evaluation of Chemical Control Measures for Termites in Maize. South African Journal of Plant and Soil, 20, 1-5. https://doi.org/10.1080/02571862.2003.10634896

[4] Sekamatte, M., Latigo, M. and Smith, A. (2001) The Effect of Maize Stover Used as Mulch on Termite Damage to Maize and Activity of Predatory Ants. African Crop Science Journal, 9, 411-419. https://doi.org/10.4314/acsj.v9i2.27612

[5] Sileshi, G.W., Kuntashula, E., Matakala, P. and Nkunika, P.O. (2007) Farmers' Perceptions of Tree Mortality, Pests and Pest Management Practices in Agroforestry in Malawi, Mozambique and Zambia. Agroforestry Systems, 72, 87-101. https://doi.org/10.1007/s10457-007-9082-5

[6] Abdurahman, A. (1990) Foraging Activity and Control of Termites in Western Ethiopia. PhD Thesis, University of London, London.

[7] Abdurahman, A. (2000) Termites as Structural Pests in Ethiopia. In: Termite Biology and Management, Report of the UNEP/FAO/Global IPM Facility Workshop, UNEP Chemicals, Geneva, 16.

[8] Umeh, V., Waliyar, F., Traoré, S. and Egwurube, E. (1999) Soil Pests of Groundnut in West Africa Species Diversity, Damage and Estimation of Yield Losses. International Journal of Tropical Insect Science, 19, 131-140. https://doi.org/10.1017/S174275840001938X

[9] Gold, C. and Wightman, J. (1991) Effects of Intercropping Groundnut with Sunnhemp on Termite Incidence and Damage in India. International Journal of Tropical Insect Science, 12, 177-182. https://doi.org/10.1017/S174275840002066X

[10] Machar, Y., Benjamin, M.J. and Tahir, C.D.E. (2016) Coconut Seedling (Cocos nucifera) Losses Due to Termite Pest Species and Possible Control Measures. African Journal of Agriculture, 3, 148-153.

[11] Mwalongo, G.C., Mkayula, L.L., Mubofu, E.B. and Mwingira, B.A. (1999) Preventing Termite Attack. Environmentally Friendly Chemical Combinations of Cashew Nut Shell Liquid, Sulfited Wattle Tannin and Copper (II) Chloride. Green Chemistry, 1, 13-16. https://doi.org/10.1039/a808022d

[12] Abate, T., van Huis, A. and Ampofo, J. (2000) Pest Management Strategies in Traditional Agriculture: An African Perspective. Annual Review of Entomology, 45, 631-659. https://doi.org/10.1146/annurev.ento.45.1.631

[13] Townson, H. (1990) Public Health Impact of Pesticides Used in Agriculture. Geneva: World Health Organization, 1990. 128 pp. Price Sw. fr. 21.00. ISBN 92-4-156139-4. Transactions of the Royal Society of Tropical Medicine and Hygiene, 86, 350. https://doi.org/10.1016/0035-9203(92)90345-D

[14] Weichenthal, S., Moase, C. and Chan, P. (2010) A Review of Pesticide Exposure and Cancer Incidence in the Agricultural Health Study Cohort. Environmental Health Perspectives, 118, 1117-1125. https://doi.org/10.1289/ehp.0901731

[15] Yadav, I.C., Devi, N.L., Syed, J.H., Cheng, Z., Li, J., Zhang, G. and Jones, K.C. (2015) 
Current Status of Persistent Organic Pesticides Residues in Air, Water, and Soil, and Their Possible Effect on Neighboring Countries: A Comprehensive Review of India. Science of the Total Environment, 511, 123-137. https://doi.org/10.1016/j.scitotenv.2014.12.041

[16] Arannilewa, S., Ekrakene, T. and Akinneye, J. (2006) Laboratory Evaluation of Four Medicinal Plants as Protectants against the Maize Weevil, Sitophilus zeamais (Mots). African Journal of Biotechnology, 5, 2032-2036.

[17] Adedire, C.O., Obembe, O.M., Akinkurolere, R.O. and Oduleye, S.O. (2011) Response of Callosobruchus maculatus (Coleoptera: Chrysomelidae: Bruchinae) to Extracts of Cashew Kernels. Journal of Plant Diseases and Protection, 118, 75-79. https://doi.org/10.1007/BF03356385

[18] Mugisha-Kamatenesi, M., Deng, A., Ogendo, J., Omolo, E., Mihale, M., Otim, M., Buyungo, J. and Bett, P. (2008) Indigenous Knowledge of Field Insect Pests and Their Management around Lake Victoria Basin in Uganda. African Journal of Environmental Science and Technology, 2, 342-348.

[19] Kamatenesi-Mugisha, M., Buyungo, J.P., Ogwal, P., Kasibante, A., Deng, A.L., Ogendo, J.O. and Mihale, M.J. (2013) Oral Acute Toxicity Study of Selected Botanical Pesticide Plants Used by Subsistence Farmers around the Lake Victoria Basin. African Journal of Environmental Science and Technology, 7, 93-101.

[20] Kuiate, J.R., Bessiere, J.M., Zollo, P.H.A. and Kuate, S.P. (2006) Chemical Composition and Antidermatophytic Properties of Volatile Fractions of Hexanic Extract from Leaves of Cupressus lusitanica Mill. from Cameroon. Journal of Ethnopharmacology, 103, 160-165. https://doi.org/10.1016/j.jep.2005.07.022

[21] Chebet, F., Deng, A.L., Ogendo, J.O., Kamau, A.W. and Bett, P.K. (2013) Bioactivity of Selected Plant Powders against Prostephanus truncatus (Coleoptera: Bostrichidae) in Stored Maize Grains. Plant Protection Science, 49, 34-43. https://doi.org/10.17221/56/2011-PPS

[22] Neuwinger, H.D. (2004) Plants Used for Poison Fishing in Tropical Africa. Toxicon, 44, 417-430. https://doi.org/10.1016/j.toxicon.2004.05.014

[23] Ogendo, J., Belmain, S., Deng, A. and Walker, D. (2003) Comparison of Toxic and Repellent Effects of Lantana camara L. with Tephrosia vogelii Hook and a Synthetic Pesticide against Sitophilus zeamais Motschulsky (Coleoptera: Curculionidae) in Stored Maize Grain. International Journal of Tropical Insect Science, 23, 127-135. https://doi.org/10.1017/S1742758400020348

[24] Muzemu, S., Chitamba, J. and Mutetwa, B. (2013) Evaluation of Eucalyptus tereticornis, Tagetes minuta and Carica papaya as Stored Maize Grain Protectants against Sitophilus zeamais (Motsch.)(Coleoptera: Curculionidae). Agriculture, Forestry and Fisheries, 2, 196-201. https://doi.org/10.11648/j.aff.20130205.13

[25] Mkindi, A.G., Mtei, K.M., Njau, K.N. and Ndakidemi, P.A. (2015) The Potential of Using Indigenous Pesticidal Plants for Insect Pest Control to Small Scale Farmers in Africa. American Journal of Plant Sciences, 6, 3164-3174. https://doi.org/10.4236/ajps.2015.619308

[26] Kalume, M.K., Losson, B. and Angenot, L. (2012) Rotenoid Content and in Vitro Acaricidal Activity of Tephrosia vogelii Leaf Extract on the Tick Rhipicephalus Appendiculatus. Veterinary Parasitology, 190, 204-209.

https://doi.org/10.1016/j.vetpar.2012.06.015

[27] Fang, N. and Casida, J.E. (1998) Anticancer Action of Cube Insecticide: Correlation for Rotenoid Constituents between Inhibition of NADH: Ubiquinone Oxidoreductase and Induced Ornithine Decarboxylase Activities. Proceedings of the National 
Academy of Sciences, 95, 3380-3384. https://doi.org/10.1073/pnas.95.7.3380

[28] Mello, F.B., Daniela, J., Kelly, C. and João, R.B.M. (2005) Effects of Lantana camara (Verbenaceae) on General Reproductive Performance and Teratology in Rats. Toxicon: Official Journal of the International Society on Toxinology, 45, 459-466. https://doi.org/10.1016/j.toxicon.2004.12.004

[29] Bevilacqua, A.H.V., Suffredini, I.B., Romoff, P., Lago, J.H.G. and Bernardi, M.M. (2011) Toxicity of Apolar and Polar Lantana camara L. Crude Extracts in Mice. Research in Veterinary Science, 90, 106-115. https://doi.org/10.1016/j.rvsc.2010.05.001

[30] Chaudhary, S., Kanwar, R.K., Sehgal, A. and Cahill D.M. (2017) Progress on Azadirachta indica Based Biopesticides in Replacing Synthetic Toxic Pesticides. Journal of Frontier of Plant Sciences, 8, 1-13. https://doi.org/10.3389/fpls.2017.00610

[31] Southwell, I.A., Russell, M.F., Maddox, C.D.A. and Wheeler, G.S. (2003) Differential Metabolism of 1,8-cineole in Insects. Journal of Chemical Ecology, 29, 83-94. https://doi.org/10.1023/A:1021976513603

[32] Bett, P.K., Deng, A.L., Ogendo, J.O., Kariuki, S.T., Kamatenesi-Mugisha, M., Mihale, J.M. and Torto, B. (2016) Chemical Composition of Cupressus lusitanica and Eucalyptus saligna Leaf Essential Oils and Bioactivity against Major Insect Pests of Stored Food Grains. Industrial Crops and Products, 82, 51-62. https://doi.org/10.1016/j.indcrop.2015.12.009

[33] Fadamiro, H., Li, C., Clement, A.-M. and Setzer, W.N. (2010) Antennal Electrophysiological Responses of the Giant Swallowtail Butterfly, Papilio cresphontes, to the Essential Oils of Zanthoxylum clavaherculis and Related Plants. Chemoecology, 20, 25-33. https://doi.org/10.1007/s00049-009-0039-1

[34] Kahimba, F.C., Mutabazi, K.D., Tumbo, S.D., Masuki, K.F. and Mbungu, W.B. (2014) Adoption and Scaling-Up of Conservation Agriculture in Tanzania: Case of Arusha and Dodoma Regions. Natural Resources, 5, 161-176.

https://doi.org/10.4236/nr.2014.54016

[35] Kimaro, E., Mlangwa, J., Lyimo-Macha, J. and Kimaro, J. (2013b) The Influence of Women Groups on Income Obtained from Small-Scale Dairy Cattle Production: Acase of Arumeru District, Tanzania. Livestock Research for Rural Development, 25, 21-27.

[36] Afari-Sefa, V., Chagomoka, T., Karanja, D.K., Njeru, E., Samali, S., Katunzi, A., et al. (2012) Private Contracting versus Community Seed Production Systems: Experiences from Farmer-Led Seed Enterprise Development of Indigenous Vegetables in Tanzania. In: Hannweg, K. and Penter, M., Eds., II All Africa Horticulture Congress Vol. 1007, ISHS, Leuven, 671-680.

[37] Kimaro, E.G., Lymo-Macha, J.G. and Jeckoniah, J.N. (2013) Gender Roles in Smallholder Dairy Farming: Pertinent Issues on Access and Control over Dairy Farming Resources in Arumeru District, Tanzania. Livestock Research for Rural Development, 25, No. 5 .

[38] Elisante, F., Tarimo., M.T. and Ndakidemi, P.A. (2013) Allelopathic Effect of Seed and Leaf Aqueous Extracts of Datura stramonium on Leaf Chlorophyll Content, Shoot and Root Elongation of Cenchrus ciliaris and Neonotonia wightii. American Journal of Plant Sciences, 4, 2332. https://doi.org/10.4236/ajps.2013.412289

[39] Coulibaly, T., Boga, J.-P., Yapi, A. and Kouassi Kouassi, P. (2013) Effects of Continuous Cultivation of Soil on Termites (Isoptera) Diversity and Abundance in Savannas of Northern of Côte d'Ivoire. Asian Journal of Agriculture and Rural Development, 3, 1-19.

[40] Bouilon, A. and Mathot, G. (1965) Identification Keys for Termites Occurring in 
East Africa.

[41] Pearce, M.J., Bacchus, S. and Logan, J. (1992) What Termite? A Guide to Identification of Termite Pest Genera in Africa. Natural Resources Institute, Greenwich.

[42] Gitonga, W., Maniania, N.K., Eilenberg, J. and Ocheil, G.R.S. (1995) Pathogenecity of Indigenous Enthomopathogenic Fungi Metarhizium anispliae and Beauveria bassiania to Macrotermes michaelseni in Kenya. Proceedings of the 2 nd Regional Workshop on Termite Research and Control, Nairobi, 7-9 March 1995, 36-44.

[43] Addisu, S., Mohamed, D. and Woktole, S. (2014) Efficacy of Botanicals Extracts against Termites Macrotermes spp. under Laboratory Conditions. International Journal of Agricultural Research, 9, 60-73. https://doi.org/10.3923/ijar.2014.60.73

[44] Joshi, P.K., Singh, N.P., Singh, N.N., Gerpacio, R.V. and Pingali, P.L. (2005) Maize in India: Production Systems, Constraints, and Research Priorities. D.F. Cimmyt, Mexico, 22.

[45] Sileshi, G.W., Nyeko, P., Nkunika, P.O., Sekematte, B.M., Akinnifesi, F.K. and Ajayi, O.C. (2009) Integrating Ethno-Ecological and Scientific Knowledge of Termites for Sustainable Termite Management and Human Welfare in Africa. Ecology and Society, 14, 48. https://doi.org/10.5751/ES-02877-140148

[46] Maayiem, D., Bernard, B.N. and Irunuoh, A.O. (2012) Indigenous Knowledge of Termite Control: A Case Study of Five Farming Communities in Gushegu District of Northern Ghana. Journal of Entomology and Nematology, 4, 58-64.

[47] Koona, P. and Dorn, S. (2005) Extracts from Tephrosia vogelii for the Protection of Stored Legume Seeds against Damage by Three Bruchid Species. Annals of Applied Biology, 147, 43-48. https://doi.org/10.1111/j.1744-7348.2005.00006.x

[48] Mkenda, P.A., Stevenson, P.C., Ndakidemi, P., Farman, D.I. and Belmain, S.R. (2015) Contact and Fumigant Toxicity of Five Pesticidal Plants against Callosobruchus maculatus (Coleoptera: Chrysomelidae) in Stored Cowpea (Vigna unguiculata). International Journal of Tropical Insect Science, 35, 172-184.

https://doi.org/10.1017/S174275841500017X

[49] Iloba, B. and Ekrakene, T. (2006) Comparative Assessment of Insecticidal Effect of Azadirachta indica, Hyptis suaveolens and Ocimum gratissimum on Sitophilus zeamais and Callosobruchus maculatus. Journal of Biological Sciences, 63, 626-630. https://doi.org/10.3923/jbs.2006.626.630

[50] El-Samahy, M., El-Ghobary, A.M. and Khafagy, I. (2014) Using Silica Nanoparticles and Neem Oil Extract as New Approaches to Control Tuta absoluta (meyrick) in Tomato under Field Conditions. International Journal of Plant and Soil Science, 3, 1355-1365. https://doi.org/10.9734/IJPSS/2014/8435

[51] Singha, D., Singha, B. and Dutta, B. (2010) In Vitro Pathogenicity of Bacillus thuringiensis against Tea Termites. Journal of Biological Control, 24, 279-281.

[52] Jasmi, A.H. and Ahmad, A.H. (2011) Termite Incidence on an Araucaria Plantation Forest in Teluk Bahang, Penang. Insects, 2, 469-474. https://doi.org/10.3390/insects2040469

[53] Tsegay, B.A., Weldeyes, A.T. and Cardelús, C.L. (2018) Traditional Use of Botanicals in Reducing Post Harvest Loss at Crop Stacking Stage in Ethiopia: A Case of Farta District. Indian Journal of Traditional Knowledge, 17, 534-541.

[54] Dua, V., Pandey, A., Singh, R., Sharma, V. and Subbarao, S. (2003) Isolation of Repellent Ingredients from Lantana camara (Verbenaceae) Flowers and Their Repellency against Aedes Mosquitoes. Journal of Applied Entomology, 127, 509-511. https://doi.org/10.1046/j.1439-0418.2003.00789.x 
[55] Mkindi, A., Mpumi, N., Tembo, Y., Stevenson, P.C., Ndakidemi, P.A., Mtei, K., Machunda, R. and Belmain, S.R. (2017) Invasive Weeds with Pesticidal Properties as Potential New Crops. Industrial Crops and Products, 110, 113-122. https://doi.org/10.1016/j.indcrop.2017.06.002

[56] Agbon, A., Ofojekwu, C. and Ezenwaka, I. (2004) Acute Toxicity of Water Extract of Tephrosia vogelii Hook to Species Relevant in Aquaculture Ponds: Rotifers, Cyclops, Mosquito Larvae and Fish. Journal of Applied Ichthyology, 20, 521-524. https://doi.org/10.1111/j.1439-0426.2004.00563.x

[57] Mihale, M., Deng, A., Selemani, H., Kamatenesi, M., Kidukuli, A. and Ogendo, J. (2009) Use of Indigenous Knowledge in the Management of Field and Storage Pests around Lake Victoria Basin in Tanzania. African Journal of Environmental Science and Technology, 3, 251-259.

[58] Belmain, S.R., Amoah, B.A., Nyirenda, S.P., Kamanula, J.F. and Stevenson, P.C. (2012) Highly Variable Insect Control Efficacy of Tephrosia vogelii Chemotypes. Journal of Agricultural and Food Chemistry, 60, 10055-10063. https://doi.org/10.1021/jf3032217

[59] Stevenson, P.C., Kite, G.C., Lewis, G.P., Forest, F., Nyirenda, S.P., Belmain, S.R., Sileshi, G.W. and Veitch, N.C. (2012) Distinct Chemotypes of Tephrosia vogelii and Implications for Their Use in Pest Control and Soil Enrichment. Phytochemistry, 78, 135-146. https://doi.org/10.1016/j.phytochem.2012.02.025

[60] Ott, K.C. (2006) Rotenone. A Brief Review of Its Chemistry, Environmental Fate, and the Toxicity of Rotenone Formulations.

[61] Reddy, P., Chitra, K. and Rao, P. (1990) Field Evaluation of Certain Plant Extracts for the Control of Brinjal Spotted Leaf Beetle, Henosepilachna vigintioctopunctata. Journal of Insect Science, 3, 194-195.

[62] Paul, U.V., Lossini, J.S., Edwards, P.J. and Hilbeck, A. (2009) Effectiveness of Products from Four Locally Grown Plants for the Management of Acanthoscelides $o b$ tectus (Say) and Zabrotes subfasciatus (Boheman)(Both Coleoptera: Bruchidae) in Stored Beans under Laboratory and Farm Conditions in Northern Tanzania. Journal of Stored Products Research, 45, 97-107. https://doi.org/10.1016/j.jspr.2008.09.006 